\title{
IN VIVO RADIOPROTECTIVE EFFECTS OF WHEATGRASS (TRITICUM AESTIVUM) EXTRACT AGAINST X-IRRADAITION-INDUCED OXIDATIVE STRESS AND APOPTOSIS IN PERIPHERAL BLOOD LYMPHOCYTES IN RATS
}

\author{
CHANDRESH SHYAM ${ }^{1}$, DEVINDER K DHAWAN ${ }^{2}$, VIJAYTA D CHADHA ${ }^{1 *}$
}

${ }^{1}$ Centre for Nuclear Medicine, Panjab University, Chandigarh, India. ${ }^{2}$ Department of Biophysics, Panjab University, Chandigarh, India. Email: vdchadha@pu.ac.in

Received: 20 October 2017, Revised and Accepted: 01 January 2018

\section{ABSTRACT}

Objectives: The present study was undertaken to investigate the possible protective potential of wheatgrass extract against radiation-induced toxicity in peripheral lymphocytes of rats exposed to a fractionated dose of X-rays.

Methods: Effects of the X-irradiation with and without wheatgrass were studied on various parameters in peripheral lymphocytes including antioxidant defense system and apoptosis. Male Sprague-Dawley rats were divided into four different groups: Normal control group, X-ray-irradiated group (21 Gy over a span of 7 days), wheatgrass-treated group ( $80 \mathrm{mg} / 100 \mathrm{~g}$ bodyweight for 2 weeks), and X-rays-irradiated + wheatgrass-treated group. All the biochemical indices which included lipid peroxidation (LPO), reduced glutathione, reactive oxygen species (ROS), and activities of antioxidant enzymes were investigated in lymphocytes. Terminal deoxynucleotidyl transferase dUTP nick-end labeling assay was carried out to assess the apoptosis in lymphocytes following whole-body X-irradiation.

Results: Whole-body X-irradiation to rats resulted in significant increase in LPO with concomitant depression of antioxidant enzymes activities, namely, superoxide dismutase, catalase, and glutathione peroxidise (GPx) in lymphocytes. Further, the present study witnessed a significant increase in the number of apoptotic lymphocytes in the X-irradiated animals. However, wheatgrass supplementation lowered the LPO levels, restored cellular antioxidant status, and provided significant protection against radiation-induced apoptosis.

Conclusions: Based on these observations, the present study suggests that wheatgrass extract has the potential to be used as an effective radioprotectant against radiation-induced oxidative stress and apoptosis in peripheral lymphocytes of whole-body X-ray-exposed rats.

Keywords: Wheatgrass, Ionizing radiation, Lymphocytes, Radioprotection, X-irradiation.

(C) 2018 The Authors. Published by Innovare Academic Sciences Pvt Ltd. This is an open access article under the CC BY license (http://creativecommons. org/licenses/by/4. 0/) DOI: http://dx.doi.org/10.22159/ajpcr.2018.v11i4.23741.

\section{INTRODUCTION}

Radiotherapy is an important non-surgical modality for the treatment of human malignancies. However, associated side effects limit its applications. Most common side effect is the suppression of hematopoietic system, which is comprised of rapidly proliferating progenitor cells and is the most radiosensitive tissue in the body [1,2]. Ionizing radiation-induced hematopoietic injury causes myelosuppression and dose-dependent depletion of circulating blood cells that result in anemia and increased susceptibility to infections [3-5]. Further, exposure to ionizing radiation has been known to inflict unprecedented long-term effect on cellular pathways, resulting in genomic instability which may later manifest into hereditary diseases or various forms of cancers [6-8]. Exposure to ionizing radiation triggers radiolysis of water in the cells that result in the generation of highly reactive free radicals $\mathrm{OH}^{\bullet}, \mathrm{H}^{\bullet}$, and $\mathrm{H}_{2} \mathrm{O}^{+}$ collectively known as reactive oxygen species (ROS) which trigger prooxidant and antioxidant imbalance [9]. ROS is known to react with various critical biomolecules such as DNA, RNA, and protein, thereby setting off disruption of cellular hemostasis [10]. Consequently, free radicals and altered molecules as an outcome of compromised cellular antioxidant defenses necessitate the development of countermeasures to minimize radiation-induced damage.

Many drugs of synthetic nature have been tested both in in vitro and in vivo models to mitigate injuries caused by ionizing radiations $[11,12]$. However, synthetic drugs have reported certain side effects
[13]. Therefore, alternative sources, especially natural herbal sources, need to be explored to be used as effective and safe radioprotectors to combat the deleterious effects of ionizing radiations. Wheatgrass is a natural herbal source and is reported to exhibit a variety of effects which are anti-inflammatory, antioxidant, antibacterial, and anti-carcinogenic in nature [14-18]. Wheatgrass is rich in flavonoids, minerals, amino acids, and vitamins $[19,20]$. Medicinal property of wheatgrass can be attributed to the presence of antioxidants, which include vanillic acid, coumaric acid, caffeic acid, and ferulic acid $[21,22]$. Wheatgrass is also known as a "green blood" as it contains a high concentration of chlorophyll and thus helps in building red blood cells and rejuvenates hematopoietic system [23,24]. There is no detailed study on radioprotective activity of wheatgrass. Moreover, there is a considerable interest in development of non-toxic radioprotector effective against adverse effects induced by ionizing radiation. Thus, the present study was conducted to explore the role of wheatgrass in mitigating the adverse effects of radiation exposure on the lymphocytes, the most susceptible targets in the blood.

\section{METHODS}

\section{Chemicals}

Terminal deoxynucleotidyl transferase dUTP nick-end labeling (TUNEL) blue apoptosis detection kit was procured from Trevigen USA. Ficoll-Histopaque-1077, 2',7'-dichlorodihydrofluorescein diacetate (DCFH-DA), bovine serum albumin, nicotinamide adenine dinucleotide phosphate (NADPH), and glutaraldehyde were procured from Sigma- 
Aldrich USA. Glutathione (GSH), nitroblue tetrazolium (NBT), and 5,5-dithiobis 2-nitrobenzoic acid (DTNB) were purchased from SRL Chemicals (India). Wheatgrass tablets were procured from a local source, manufactured and supplied by AYUSH, India. All the routine chemicals used were of analytical grade and were procured from the local supplier

\section{Animals}

A total of 32 male Sprague-Dawley rats weighing 100-150 g were obtained from the central animal house of Panjab University Chandigarh and were maintained under standard laboratory conditions. The animals were fed with standard pellet diet (Ashriwad Industries, Punjab, India) and water ad libitium. All the experiments on animals were conducted with strict adherence to the ethical guidelines as approved by the Institutional Ethics Committee of Panjab University, Chandigarh (Ref: IAEC/347-370 dated 12/02/2013). The animals were segregated randomly into four groups, and each group consisted of 8 animals. The animals in group I served as Normal control and were fed standard laboratory feed and water ad libitum. The animals in group II were subjected to whole-body X-rays exposure to deliver a total dose of 21 Gy by giving a daily exposure of 3 Gy spanned over a period of 7 days [25]. The animals were anaesthetized using mild ether anesthesia so as to immobilize them during X-ray exposure. The group III animals were given wheatgrass extract at a dose of $80 \mathrm{mg} / 100 \mathrm{~g}$ bodyweight everyday orally for 2 weeks [26]. The group IV animals were given a combined treatment of whole-body X-ray exposure as well as wheatgrass with similar doses as were given to group II and group III, respectively. Wheatgrass treatment was started one week prior to the start of first radiation exposure and continued for a total duration of two weeks. All the experimental studies were carried out $24 \mathrm{~h}$ after the last X-ray exposure in lymphocytes.

\section{$\mathrm{X}$-ray machine calibration using ferrous sulphate-benzoic acid-} xylenol orange (FBX) dosimeter

X-ray machine (Allengers Company, India) was calibrated using the FBX dosimeter as described by Gupta et al. [27]. Briefly, FBX solution in a plastic Petri dish was exposed to X-rays at a constant current $20 \mathrm{~mA}$ and varying voltages from 40 to $110 \mathrm{kV}$. Thereafter, optical density (OD) was measured after $30 \mathrm{~min}$ of exposure at $548 \mathrm{~nm}$ wavelength. Measured OD was then compared with OD of FBX samples exposed to known different doses from LINAC in the Department of Radiotherapy, Post Graduate Institute of Medical Education and Research. After calibration, a dose of 3 Gy was delivered to animals by X-ray machine at a constant voltage of $80 \mathrm{kV}$ and a constant current of $20 \mathrm{~mA}$.

\section{Lymphocyte extraction and preparation of lysate}

The blood samples were drawn at $24 \mathrm{~h}$ post irradiation by puncturing the ocular vein of rats with fine sterilized capillary, and the lymphocytes were isolated from heparinized blood samples according to the method of Hudson and Hay [28]. Briefly, $2 \mathrm{ml}$ of blood was diluted with $2 \mathrm{ml}$ of normal saline and then layered carefully on the $3 \mathrm{ml}$ histopaque 1077. The samples were centrifuged at $1800 \mathrm{rpm}$ for $20 \mathrm{~min}$ at $20^{\circ} \mathrm{C}$. White milky layer of mononuclear cells (i.e. lymphocytes) was carefully removed, and the cells were washed twice with the saline and then centrifuged at $1200 \mathrm{rpm}$ for $10 \mathrm{~min}$ to get the pellets of lymphocytes. The lymphocytes were lysed in a hypotonic solution of distilled water for $45 \mathrm{~min}$ at $37^{\circ} \mathrm{C}$ and then were centrifuged at $10,000 \mathrm{rpm}$ for $2 \mathrm{~min}$ at $4^{\circ} \mathrm{C}$. The supernatants were taken for the biochemical assays.

\section{Biochemical assays}

\section{Lipid peroxidation (LPO)}

LPO was assayed using the method of Wills [29]. Briefly, 10\% trichloroacetic acid was added to lysate and precipitated proteins were removed by centrifugation. To the supernatants, $2 \mathrm{ml}$ of $0.67 \%$ 2-thiobarbituric acid (TBA) was added and the pink color was developed at $100^{\circ} \mathrm{C}$. The samples were allowed to cool and OD of pinkcolored TBA complex was read at $532 \mathrm{~nm}$. The amount of product formed was calculated on the basis of the molar extinction coefficient of TBA complex $\left(1.56 \times 10^{5} / \mathrm{M} / \mathrm{cm}\right)$.

\section{Reduced GSH}

The levels of reduced GSH were measured according to the method of Ellman [30]. Briefly, 25\% TCA was added to the lysates to precipitate proteins and the samples were centrifuged to obtain supernatants. Freshly prepared DTNB was added to the supernatants and the OD of the yellow-colored complex was measured at $412 \mathrm{~nm}$. Molar extinction for GSH is $13600 / \mathrm{M} / \mathrm{cm}$.

\section{Catalase (CAT)}

CAT estimation was done by the following method as described by Catalase [31]. Briefly, lysates were added to the reaction mixture containing $50 \mathrm{mM}$ phosphate buffer and $12 \mathrm{mM} \mathrm{H}_{2} \mathrm{O}_{2}$. CAT present in the sample decomposes $\mathrm{H}_{2} \mathrm{O}_{2}$ and the resulting decrease in OD was measured at $240 \mathrm{~nm}$ for $3 \mathrm{~min}$. Decomposition of $\mathrm{H}_{2} \mathrm{O}_{2}$ was calculated using the molar extinction coefficient $(0.0394 / \mathrm{mM} / \mathrm{cm})$.

\section{Glutathione peroxidise (GPx)}

The activity of GPx was measured by coupled enzyme assay described by Flohé and Günzler [32]. GPx decomposes $\mathrm{H}_{2} \mathrm{O}_{2}$ by oxidizing GSH into GSSG, and this reaction is coupled with a reduction of GSSG into GSH by GSH reductase by utilizing NADPH. Utilization of NADPH results in a decrease in absorbance of NADPH which was measured at $340 \mathrm{~nm}$.

\section{Superoxide dismutase (SOD)}

SOD activity was estimated according to method of Kono [33]. Briefly, NBT is reduced to blue-colored formazon by superoxide ions generated by photo oxidation of hydroxylamine hydrochloride, and the change in absorbance was measured at $560 \mathrm{~nm}$. The addition of SOD in the sample inhibited the reduction of NBT mediated by superoxide ions. The extent of inhibition was taken as a measure of enzyme activity. One unit of enzyme was expressed as inverse of amount of protein $(\mathrm{mg})$ required to inhibit the reduction rate of NBT by $50 \%$.

\section{Protein estimation}

The estimation of protein concentration was done by the following method of Lowry et al. [34]. Briefly, lysates were diluted in distilled water to make a total volume up to $700 \mu$ l. Lowry reagent (prepared by mixing $98 \mathrm{ml}$ of $2 \%$ sodium carbonate in $0.1 \mathrm{M} \mathrm{NaOH}, 1 \mathrm{ml}$ of $1 \%$ copper sulphate and $1 \mathrm{ml}$ of $2 \%$ sodium potassium tartarate) was added to sample. Sample were then thoroughly mixed and allowed to stand for $10 \mathrm{~min}$ at room temperature. $0.25 \mathrm{ml} 1 \mathrm{~N}$ Folin reagent was added followed by immediate mixing and incubation at room temperature in the dark for $30 \mathrm{~min}$. The absorbance of the blue-colored complex was measured at $620 \mathrm{~nm}$ using spectrophotometer

\section{ROS}

ROS were estimated by the method of method of Driver et al. [35]. using DCFH-DA. The lymphocytes were incubated with $20 \mu \mathrm{M}$ DCFH-DA for $30 \mathrm{~min}$ at room temperature in the dark. ROS present in the samples activated esterases which cleaved acetate group of non-fluorescent DCFH-DA converting it into fluorescent dichlorofluorescein (DCF). The fluorescence was measured using a spectrofluorimeter at excitation wavelength $488 \mathrm{~nm}$ and emission wavelength $521 \mathrm{~nm}$. The fluorescence intensity units of DCF/mg protein were taken as the measure of ROS in different treatment groups.

\section{TUNEL assay}

Apoptosis was assessed using Trevigen TUNEL blue apoptosis detection kit. Briefly, lymphocytes were fixed in $4 \%$ formaldehyde at room temperature. The cells were then resuspended in $80 \%$ ethanol and fixed on polylysine coated slides. For TUNEL assay reaction, the slides were immersed in terminal deoxynucleotidyltransferase (TdT) enzyme labeling buffer following which slides were covered with the TdT labeling reaction mixture containing a brominated nucleotide (BrdU). The reaction was stopped after $30 \mathrm{~min}$ by putting slides in the TdT stop buffer. The labeled apoptotic cells were stained with biotinylated anti- 
BrdU antibody followed by counterstaining with nuclear fast red stain. The blue apoptotic positive cells were counted for apoptotic analyses.

\section{Statistical analysis}

Statistical analysis of the data was carried out using one-way analysis of variance on SPSS followed by multiple post hoc analyses (StudentNewman-Keuls). The results were expressed as mean \pm standard deviation.

\section{RESULTS}

The results of different treatment groups were compared with the normal control group. In addition, the results from wheatgrass + X-raytreated group were compared with radiation-treated group.

Changes in the level of LPO are presented in Table 1. A statistically significant $(p \leq 0.001)$ increase in level of MDA $(17.10 \pm 2.14)$ was observed in lymphocytes from irradiated rats against the control values (7.85 \pm 1.13$)$. However, on wheatgrass extract supplementation to X-ray-exposed rats, a significant $(\mathrm{p} \leq 0.001)$ decrease in MDA levels $(9.67 \pm 2.87)$ was observed and the indicative of its normalization.

The activities of enzymes associated with the antioxidative defense system, namely, CAT, SOD, and GPx as well as the levels of GSH were found to be significantly decreased following exposure to X-rays when compared to the normal control rats (Table 1). In irradiated group GPx activity was $2.41 \pm 0.13$, SOD activity was $23.98 \pm 2.12$, whereas CAT activity $252.00 \pm 50.08$. Interestingly, wheatgrass extract supplementation to X-ray-irradiated rats resulted in a significant increase in the activity of CAT $(416.75 \pm 4517)$, GPx $(3.07 \pm 0.26)$, and SOD (36.78 \pm 5.27$)$ in lymphocytes when compared to X-irradiated rats. The GSH content $(15.18 \pm 2.16)$ was significantly $(\mathrm{p} \leq 0.001)$ depleted in $\mathrm{X}$-irradiated rats when compared with control rats. Treatment of rats with wheatgrass extract before X-ray exposure resulted in significant increase $(p \leq 0.001)$ in GSH level $(19.93 \pm 2.34)$ when compared with irradiated group. In addition, depression in inherent antioxidant defense system in lymphocytes was accompanied by an elevated level of ROS (68.34 \pm 6.88$)$ (Table 2) in X-ray-irradiated rats when compared to normal control group $(13.01 \pm 4.28)$ as indicated by flourimetric analysis of ROS by DCFH-DA assay. Wheatgrass extract supplementation exhibited a significant protection and lowered the levels of ROS $(28.79 \pm 2.79)$ in irradiated rats.

The results of TUNEL assay in peripheral lymphocytes are shown in Fig. 1. An increase in TUNEL-positive cells was clearly noticeable in the
X-irradiated group. However, a significant reduction was observed in a number of apoptotic cells in X-ray-irradiated rats supplemented with wheatgrass when compared to X-irradiated rats, thereby indicating reduced apoptosis.

\section{DISCUSSION}

Exposure to ionizing radiations is known to suppress antioxidant defense system leading to the unhindered propagation of the deleterious effects resulting in cytogenetic instability. Wheatgrass extract has a major concentration of active components such as polyphenols, vitamins, essential elements, and chlorophyll [19-23]. In earlier studies, antioxidant and cell signal modulatory property of various components present in wheatgrass has been extensively investigated in various pathological conditions [36]. The present study investigated the protective efficacy of the wheatgrass extract in ameliorating radiation inflicted injury to X-ray-exposed lymphocytes in rats.

Ionizing radiations inflict damage to biological tissue by the way of reactive ROS produced as a consequence of interaction of radiation with water molecule [9]. ROS is known to produce prooxidant and antioxidant imbalance, resulting in cascade of biomolecular changes finally culminating in cellular dysfunction and apoptosis [10]. In addition, ROS is known to attack polyunsaturated fatty acids in Hydroxyl radical reacts with polyunsaturated fatty acid leading to formation of lipid free radicals, which are reduced by nearby fatty acids, thus starting the self-propagating process of LPO. In the present study, a marked increase was observed in MDA levels following whole-body $\mathrm{X}$-ray exposure (Table 1). Various studies have reported that exposure to ionizing radiation results in damage to membrane lipids [37-39]. In addition, the formation of hydrophilic peroxide from lipophilic unsaturated fatty acid changes membrane dynamics and results in loss of structural as well as functional integrity of membrane [40]. Alterations in membrane physicochemical properties affect function of membrane bound enzymes, permeability, and surface receptors leading to alterations in cell proliferation, differentiation, and apoptosis $[41,42]$. Interestingly, we observed that administration of wheatgrass extract to the X-irradiated rats resulted in the moderation of MDA levels. This could be accredited to active components of wheatgrass such as coumaric acid, caffeic acid, and ferulic acid which work synergistically to effectively scavenge ROS. Furthermore, elemental analysis of wheatgrass has reported a high content of essential elements such as Fe and Zn which are known to enhance cellular repair capacity [43,44]. In an earlier study from our laboratory, Zn has been reported to render

Table 1: Effect of wheatgrass extract on antioxidant status of lymphocytes of normal control and experimental rats

\begin{tabular}{|c|c|c|c|c|c|}
\hline Groups & $\begin{array}{l}\text { LPO } \\
\left(10^{-2} \text { nmoles/mg protein }\right)\end{array}$ & $\begin{array}{l}\text { GSH } \\
\text { (nmoles/mg protein) }\end{array}$ & $\begin{array}{l}\text { SOD } \\
\text { (Ua/mg protein) }\end{array}$ & $\begin{array}{l}\text { CAT } \\
\text { (U } \mathrm{U}^{\mathrm{b}} / \mathrm{mg} \text { protein) }\end{array}$ & $\begin{array}{l}\text { GPX } \\
\text { (UC/mg protein) }\end{array}$ \\
\hline Normal control & $7.85 \pm 1.13$ & $23.64 \pm 1.24$ & $41.52 \pm 9.35$ & $549.50 \pm 52.50$ & $3.59 \pm 0.33$ \\
\hline X-ray irradiated & $17.10 \pm 2.14^{* * *}$ & $15.18 \pm 2.16^{* * *}$ & $23.98 \pm 2.12^{* * *}$ & $252.00 \pm 50.08^{* * *}$ & $2.41 \pm 0.13^{* * *}$ \\
\hline Wheatgrass & $8.82 \pm 1.91$ & $21.18 \pm 1.17$ & $36.67 \pm 6.69$ & $555.33 \pm 60.88$ & $3.50 \pm 0.16$ \\
\hline X-ray & $9.67 \pm 2.87^{\# \# \#}$ & $19.93 \pm 2.34 * *$,\#\# & $36.78 \pm 5.27^{\# \#}$ & $416.75 \pm 45.17 * *$,\#\#\# & $3.07 \pm 0.26^{\# \#}$ \\
\hline
\end{tabular}

$\mathrm{U}^{\mathrm{a}}=50 \%$ inhibition of nitroblue tetrazolium reduction in $1 \mathrm{~min} . \mathrm{U}^{\mathrm{b}}=\mu$ moles of hydrogen peroxide consumed per minute. $\mathrm{U}^{\mathrm{c}}=\mu \mathrm{moles}$ of $\mathrm{NADPH}$ utilized/min $/ \mathrm{mg}$ protein. ${ }^{*} \mathrm{p} \leq 0.05,{ }^{* *} \mathrm{p} \leq 0.01,{ }^{* * *} \mathrm{p} \leq 0.001$ when compared to normal control group. ${ }^{\#} \mathrm{p} \leq 0.05$, ${ }^{\# \#} \mathrm{p} \leq 0.01,{ }^{*} \# \mathrm{p} \leq 0.001$ when $\mathrm{X}$-ray irradiated wheatgrass-treated group compared to X-ray-irradiated group. Values are expressed as mean \pm SD, $n=8$ animals. LPO: Lipid peroxidation, GSH: Glutathione, SOD: Superoxide dismutase, GPx: Glutathione peroxidase, CAT: Catalase, SD: Standard deviation, NADPH: Nicotinamide adenine dinucleotide phosphate

Table 2: Effect of wheatgrass extract on ROS levels in lymphocytes in the Normal control and experimental rats

\begin{tabular}{ll}
\hline Groups & Lymphocytes (DCF fluorescent intensity units/mg protein) \\
\hline Normal control & $13.01 \pm 4.28$ \\
X-ray irradiated & $68.34 \pm 6.88^{* * *}$ \\
Wheatgrass & $23.35 \pm 4.74$ \\
X-rayirradiated+Wheatgrass & $28.79 \pm 2.79^{* * *}, \# \#$ \\
\hline
\end{tabular}

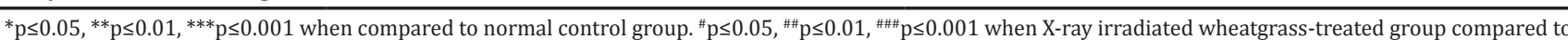

$\mathrm{X}$-ray irradiated group. Values are expressed as mean \pm SD, $n=8$ animals. SD: Standard deviation, ROS: Reactive oxygen species, DCF: Dichlorofluorescein 


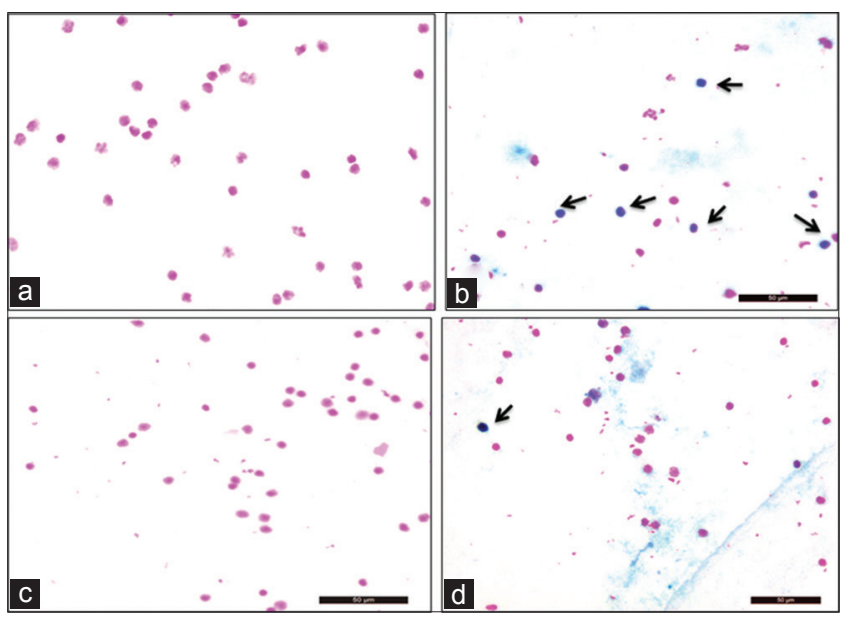

Fig. 1: Terminal deoxynucleotidyl transferase dUTP nickend labeling (TUNEL) staining of lymphocytes of (a) normal control, (b) X-ray irradiated, (c) wheatgrass-treated, and (d) X-ray+wheatgrass-treated rats, respectively $(\times 40)$. Lymphocytes with 3'OH tagged with brominated nucleotide are TUNEL-positive cells and appear blue, and lymphocytes with intact DNA strand are TUNEL negative and appear pink with nuclear fast red stain

protection against $\mathrm{t}^{131}$ I-induced radiation damage to cell membrane [45]. Further, Zn has been observed to stimulate antioxidant defense system to contain free radicals induced damage to biological tissue. Therefore, augmented effect of antioxidants and micronutrients present in the wheatgrass extract reverses cellular membrane damage.

To counteract increased ROS, cells possess comprehensive enzymatic (SOD, CAT, and GPx) and non-enzymatic (GSH) defense system. GSH, a potent endogenous antioxidant is involved in direct reduction of ROS while being oxidized itself [46]. In the present study, we observed radiation-induced oxidative stress that led to increased utilization of GSH and consequently depleted GSH levels (Table 1). Further, depleted GSH levels have been linked with increased LPO which corroborates well with our findings of increased LPO [47]. Antioxidants present in wheatgrass counteract free radicals in X-ray-exposed rats and maintain optimal GSH levels. GSH is known to work in coordination with GPx enzyme which maintains is involved in reduction of GSSG and depleted GSH is known to inhibit GPx activity [48]. Thus, in the present study, we observed dramatic depression in the activity of GPx. The activities of endogenous antioxidant enzymes are closely linked, and thus, decreased GPx activity also results in a significant decline in the activities of SOD and CAT (Table 1). The plausible explanation of decreased activity of SOD and CAT could be due to overwhelming of these enzymes to neutralize the increased amounts of superoxide ions and hydrogen peroxide that are formed by radiolysis of water as a consequence of interaction with X-rays [49]. The present study clearly indicates that wheatgrass supplementation significantly improves the activities of SOD, CAT, and GPx. Another plausible factor for the amelioration of enzymatic activity could be attributed to the presence of micronutrients such as $\mathrm{Mn}, \mathrm{Fe}$, and $\mathrm{Zn}$ which are associated as cofactors in the activation of enzymes SOD and CAT [50,51].

Severity of radiation damage leads to break in DNA strand, thereby leading to initiation of apoptosis [52]. TUNEL assay is cited as a highly specific biomarker for apoptosis detection by labeling apoptotic cell at genetic level. In our study, we have seen an increase in TUNEL positive cells following X-irradiated which, however, were brought down appreciably on simultaneous wheatgrass supplementation (Fig. 1). Furthermore, the end product of LPO, MDA and 4-hydroxynonenal binds to DNA base pairs and initiates apoptotic signal transduction [53]. Apoptotic cells in irradiated group were brought down appreciably on simultaneous wheatgrass supplementation. Although the exact mechanism by which wheatgrass prevents apoptosis is not clear, it is understandably due to the antioxidant activities of bioactive components of wheatgrass or DNA repair enhancing property of micronutrients such as $\mathrm{Mg}$ and $\mathrm{Zn}[54,55]$. In addition, wheatgrass is a rich source of chlorophyll which is known for inducing DNA repair and has the ability to trap mutagenic substances, thus preventing indirect DNA damage induced by MDA [56].

\section{CONCLUSION}

On the basis of the results from the study, we conclude that whole-body X-ray exposure compromises antioxidant defense system and results in ROS-induced apoptosis in lymphocytes. Wheatgrass supplementation offers the non-toxic radioprotective ability to protect lymphocytes from $\mathrm{X}$-irradiation-induced damage. However, further studies are warranted with regard to other definitive bioassays including protein expressions and documentation of specific molecular markers to establish the exact mechanism for wheatgrass-mediated radioprotection.

\section{ACKNOWLEDGMENT}

We are thankful to Indian Council of Medical Research (ICMR) for providing financial support for the above project (Senior Research Fellowship No. 45/43/2013/BMS/TRM)

\section{AUTHOR CONTRIBUTION}

All the persons who have participated in the study have been listed as authors.

- Conception and design of the study: Chandresh Shyam, Devinder K Dhawan, Vijayta D Chadha

- Revision and Drafting of the manuscript: Chandresh Shyam, Devinder K Dhawan, Vijayta D Chadha

\section{CONFLICT OF INTEREST}

The authors report no conflicts of interest. The authors alone are responsible for the content and writing of the paper.

\section{REFERENCES}

1. Bond VP, Fliendner TM, Archambeau JO. Mammalian Radiation Lethality: A Disturbance in Cellular Kinetics. New York: Academic Press; 1965.

2. Goans RE, Holloway EC, Berger ME, Ricks RC. Early dose assessment following severe radiation accidents. Health Phys 1997;72:513-8.

3. Mauch P, Constine L, Greenberger J, Knospe W, Sullivan J, Liesveld JL, et al. Hematopoietic stem cell compartment: Acute and late effects of radiation therapy and chemotherapy. Int $\mathrm{J}$ Radiat Oncol Biol Phys 1995;31:1319-39.

4. Morgan WF. Radiation-induced genomic instability. Health Phys 2011;100:280-1.

5. Dainiak N. Hematologic consequences of exposure to ionizing radiation. Exp Hematol 2002;30:513-28.

6. Jagetia GC, Venkatesha VA. Mangiferin protects human peripheral blood lymphocytes against $\gamma$-radiation-induced DNA strand breaks: A fluorescence analysis of DNA unwinding assay. Nutr Res 2006;26:303-11.

7. Ozasa K, Shimizu Y, Suyama A, Kasagi F, Soda M, Grant EJ, et al. Studies of the mortality of atomic bomb survivors. Report 14, 19502003. An overview of cancer and noncancer diseases. Radiat Res 2012;177:229-43.

8. Riley PA. Free radicals in biology: Oxidative stress and the effects of ionizing radiation. Int J Radiat Biol 1994;65:27-33.

9. Bhosle SM, Huilgol NG, Mishra KP. Enhancement of radiation-induced oxidative stress and cytotoxicity in tumor cells by ellagic acid. Clin Chim Acta 2005;359:89-100.

10. Von Sonntag C. The Chemical Basis of Radiation Biology. London: Taylor \& Francis; 1987. p. 65-84

11. Livesey JC, Reed DJ. Chemical protection against ionizing radiation. Adv Radiat Res 1987;13:285-353.

12. Mansour HH, Hafez HF, Fahmy NM, Hanafi N. Protective effect of $\mathrm{N}$-acetylcysteine against radiation induced DNA damage and hepatic toxicity in rats. Biochem Pharmacol 2008;75:773-80

13. Glowe PJ, Glick JH, Weiler C. Phase I trials of WR 2721 and 
Cisplatinum. Int J Radiat Oncol Biol Phys 1984;10:1781-7.

14. Aydos OS, Avci A, Ozkan T, Karadag A, Gurleyik E, Altinok B, et al. Antiproliferative, apoptotic and antioxidant activities of wheatgrass (Triticumaestivum L.) extract on CML (K562) cell line. Turk J Med Sci 2011;41:657-63.

15. Lee SH, Lee YM, Lee HS, Kim DK. Antioxidative and antihyperglycemia effects of Triticumaestivum wheat sprout water extracts on the Streptozotocin-induced diabetic mice. Korean J Pharmacogn 2009;40:408-14.

16. Peryt B, Szymczyk T, Lesca P. Mechanism of antimutagenicity of wheat sprout extracts. Mutat Res 1992;269:201-15.

17. Tandon S, Arora A, Singh S, Monga J, Arora S. Antioxidant profiling of Triticumaestivum (wheatgrass) and its antiproliferative activity in MCF7 breast cancer cell line. J Pharm Res 2011;4:4601-4.

18. Yi B, Kasai H, Lee HS, Kang Y, Park JY, Yang M. Inhibition by wheat sprout (Triticumaestivum) juice of bisphenol A-induced oxidative stress in young women. Mutat Res 2011;724:64-8.

19. Calzuola I, Gianfranceschi GL, Marsili V. Comparative activity of antioxidants from wheat sprouts, Morinda citrifolia, fermented papaya and white tea. Int J Food Sci Nutr 2006;57:168-77.

20. Kulkarni SD, Acharya R, Nair AG, Rajurkar NS, Reddy AV. Determination of elemental concentration profiles in tender wheatgrass (Triticumaestivum L.) using instrumental neutron activation analysis. Food Chem 2006;95:699-707.

21. Benincasa P, Galieni A, Manetta AC, Pace R, Guiducci M, Pisante M, et al. Phenolic compounds in grains, sprouts and wheatgrass of hulled and non-hulled wheat species. J Sci Food Agric 2015;95:1795-803.

22. Tyl CE, Bunzel M. Antioxidant activity-guided fractionation of blue wheat (UC66049 Triticumaestivum L.). J Agric Food Chem 2012;60:731-9.

23. Shirude AA. Phytochemical and pharmacological screening of wheatgrass juice (Triticumaestivum L.). Int J Pharm Sci Rev Res 2011;9:159-64.

24. Singh K, Pannu MS, Singh P, Singh J. Effects of wheat grass tablets on the frequency of blood transfusions in Thalassemia Major. Indian J Pediatr 2010;77:90-1.

25. Sharma P, Singla N, Dhawan DK. Evidence of zinc in affording protection against X-ray-induced brain injury in rats. Biol Trace Elem Res 2017; 179:247-58.

26. Kamboj JK, Rana SV, Dhawan DK, Vahiphei K. Role of wheatgrass in prevention of carbon tetrachloride induced hepatotoxicity in rats. J Clin Exp Hepatol 2011;1:S1.

27. Gupta BL, Bhat RM, Gomathy KR, Susheela B. Radiation chemistry of ferrous sulphate-benzoic and xylenol orange system. Radiat Res 1978;75:269-77.

28. Hudson L, Hay FC. Practical Immunology. $4^{\text {th }}$ ed. Oxford: Blackwell Scientific Publications; 1991

29. Wills ED. Mechanism of lipid peroxide formation in animal tissues. Biochem J 1966;99:667-76.

30. Ellman GL. Tissue sulfhydryl groups. Arch Biochem Biophys 1959;82:70-7.

31. Catalase LH. In: Bergmeyer HU, editor. Methods of Enzymatic Analysis. New York: Academic Press; 1971. p. 885-93.

32. Flohé L, Günzler WA. Assays of glutathione peroxidase. In: Packer L, editor. Methods in Enzymology. New York: Academic; 1984. p. 114-21.

33. Kono Y. Generation of superoxide radical during auto oxidation of hydroxylamine and an assay for superoxide dismutase. Arch Biochem Biophys 1978;186:189-95.

34. Lowry OH, Rosebrough NJ, Farr AL, Randall RJ. Protein measurementswith the Folin-phenol reagent. J Biol Chem 1951;193:265-75.

35. Driver AS, Kodavanti PR, Mundy WR. Age-related in reactive oxygen species production in rat brain homogenates. Neurotoxicol Teratol $2000 ; 22: 175-81$
36. Singh N, Verma P, Pandey BR. Therapeutic potential of organic TriticumaestivumLinn. (Wheatgrass) in prevention and treatment of chronic diseases: An Overview. Int J Pharm Sci Drug Res 2012;4:10-4.

37. Edwards JC, Chapman D, Cramp WA, Yatvin MB. The effects of ionizing radiation on biomembrane structure and function. Prog Biophys Mol Biol 1984;43:71-93.

38. Ianzini F, Guidoni L, Indovina PL, Viti V, Erriu G, Onnis S, et al. Gamma-irradiation effects on phosphatidylcholine multilayer liposomes: Calorimetric, NMR, and spectrofluorimetric studies. Radiat Res 1984;98:154-66.

39. Sheriff NH, Hawas AM, Abdallah WE, Saleh IA, Shams KA, Hammouda FM. Potential role of milk thistle seed and its oil extracts against heart and brain injuries induced by $\gamma$-radiation exposure. Int $\mathrm{J}$ Pharm Pharm Sci 2017;9:52-8.

40. Pamplona R. Advanced lipoxidation end-products. Chem Biol Interact 2011;192:14-20.

41. García-Gil FA, Albendea CD, López-Pingarrón L, Royo-Dachary P, Martínez-Guillén J, Piedrafita E, et al. Altered cellular membrane fluidity levels and lipid peroxidation during experimental pancreas transplantation. J Bioenerg Biomembr 2012;44:571-7.

42. Srinivasan M, Sudheer AR, Rajasekaran KN, Menon VP. Effects of curcuminanalog on $\gamma$-radiation induced cellular changes in primary culture of isolated rat hepatocytes in vitro. Chem Biol Interact 2008; $176: 1-8$

43. Goel A, Dani V, Dhawan DK. Protective effects of zinc on lipid peroxidation, antioxidant enzymes and hepatic histoarchitecture in chlorpyrifos-induced toxicity. Chem Biol Interact 2005;156:131-40.

44. Prá D, Franke SI, Henriques JA, Fenech M. Iron and genome stability: An update. Mutat Res 2012;733:92-9.

45. Dani V, Dhawan DK. Zinc as an antiperoxidative agent following iodine-131 induced changes on the antioxidant system and on the morphology of red blood cells in rat. Hell J Nucl Med 2006;9:22-6.

46. Malhotra A, Dhawan DK. Zinc improves antioxidative enzymes in red blood cells and hematology in lithium-treated rats. Nutr Res 2008;28:43-50.

47. Younes M, Siegers CP. Mechanistic aspects of enhanced lipid peroxidation following glutathione dependent depletion in vivo. Chem Biol Interact 1981;34:257-66.

48. Cario E, Jung S, Harder D'Heureuse J, Schulte C, Sturm A, Wiedenmann B, et al. Effects of exogenous zinc supplementation on intestinal epithelial repair in vitro. Eur J Clin Invest 2000;30:419-28.

49. Manasaveena V, Akula KK, Sangram V. A comparative evaluation of enzymatic antioxidant levels in pre and post therapy patients with oral cancer. Int J Pharm Pharm Sci 2014;6:52-6.

50. Fraga CG. Relevance, essentiality and toxicity of trace elements in human health. Mol Aspects Med 2005;26:235-44.

51. Matés JM, Sánchez-Jiménez F. Antioxidant enzymes and their implications in pathophysiologic processes. Front Biosci 1999;4:D339-45.

52. Kumari SN, Sanjeev G, Rao VC. Effect of ethanolic extract of Cyanotis cristata leaves applied topically on wound healing in wistar rats. Int J Pharm Pharm Sci 2015;7:63-7.

53. Eder E, Wacker M, Lutz U, Nair J, Fang X, Batsch H, et al. Oxidative stress related DNA adducts in the liver of female rats fed with sunflower, rapeseed, olive or coconut oil supplemented diets. Chem Biol Interact 2006;159:81-9.

54. Hartwig A. Role of magnesium in genomic stability. Mutat Res 2001:475:113-21

55. Ho E. Zinc deficiency, DNA damage and cancer risk. J Nutr Biochem 2004; $15: 572-8$.

56. Hsu CY, Yang CM, Chen CM, Chao PY, Hu SP. Effects of chlorophyllrelated compounds on hydrogen peroxide induced DNA damage within human lymphocytes. J Agric Food Chem 2005;53:2746-50. 